\title{
Domestic Animals in English and Iraqi Rural Proverbs: A Pragma stylistic Study
}

\section{Asst. professor Mahdi Khalaf Hussein Al- Janabi (Ph.D.} E-mah_jan49@yahoo.com AL-Mamun University College, Department of Translation, Baghdad, Iraq DOI: https://doi.org/10.36586/jcl.2.2020.0.41.0001

\section{(c) (1)}

This work is licensed under a Creative Commons Attribution 4.0 International License.

\section{Abstract}

Proverbs gain their importance not only from the fact that they represent a cultural record of the people of every nation, but they reveal the way they use language and how they exploit their environments as a good source of inspiration to enrich that language. Domestic animals, as part of every environment, play a major role in composing proverbs in every nation.

This study is an attempt to pragmastylistically analyse some selected English and Iraqi rural proverbs using domestic animals in their texts. It limits itself to investigate certain stylistic and pragmatic devices such as: the type of sentences, their lengths, their content and grammatical words, the part of speech used, metaphor, repetition, the kinds of illocutionary forces, the types of the speech acts and the anaphoric references.

This study draws some conclusions from which are the following: -that the gap in culture does not affect the use of similar proverbs semantically and pragmatically,

- the English sentence is longer than the Arabic sentence, and

- the two types of proverbs use the same illocutionary forces. 
Key Words: Proverb, Stylistics, Pragmatics, Pragmastylistics, and Speech act theory.

\section{Introduction}

Proverbs in every nation are part of its precious heritage. They form the main part in the ingredients of the popular knowledge. Nations might differ in their culture but have the same approaches to avail their environments for innovating proverbs that reflect their life. All nations are inspired by the existence of the domestic animals to compose a considerable part of their proverbs.

This study aims at analysing some selected English and Iraqi rural proverb using domestic animals in their texts. Within a pragmastylistic approach, the proverbs are analyesd stylistically and pragmatically. The stylistic analysis investigates such devices like; types of sentences, their lengths, their content and grammatical words, the parts of speech used in them, metaphor, alliteration and repetition. The pragmatic analysis covers the semantic and pragmatic comparison between the two types of proverbs. The kinds of the illocutionary forces, the types of the speech acts and the anaphoric references are traced.

\section{Proverbs}

Kerschen (1998:3) states that "Proverbs are difficult to define. While much has been written on what a proverb is, it is more important to understand what a proverb does. A proverb is a short homely statement that teaches a lesson or gives practical advice" Proverbs gain their importance from their value in the life, language, and culture of every people. They are considered as the heritage of any nation of experience and expertise (Attia: 
2004:3). Within the same sense Speake and Simpson (2004: v) define proverb as "a traditional saying which offers advice or present a moral in short and pithy manner" Proverbs are not only readymade expressions offering advice or cherishing morals, but they describe and present truths and human observation as well. Manser (2007:IX) highlights the meaning and function of proverb "A proverb is a saying, usually short, that expresses a general truth about life. Proverbs give advice, make an observation, or present a teaching in a succinct and memorable way". A proverb has certain characteristics that distinguish it from other expressions. Al-Hanafi (1962) in his introduction opines that the most important features of proverbs are brevity and splendor style. A proverb has to be common among people for a long time and must include a general and lasting wisdom. No saying elevates the rank of proverbs unless it proves its sincerity time after time.

A proverb can be defined generally as a common saying that holds the sense of advice or warning. Oxford Advanced Learner's Dictionary (2005: sv proverb) defines the word proverb as "a well- known phrase or sentence that gives advice or says sth that is generally true" Stone (2006: xii) affirms that "proverbs are common to nearly all cultures, ancient and modern, literate and non-literate. Generally speaking, proverbs are popular sayings that express commonly held truths, with their chief ingredients"

Barajas (2010:50) explains that "one quintessential characteristic of proverbs is that they serve a comparative function between what appear to be at least two initially unrelated referents"

In addition to their socio-communicative situations, proverbs aim at:

(1) to support an argumentative claim concerning behavior;

(2) to teach or promote reflection by way of advice; or

(3) to establish interpersonal rapport, and

(4) to add variety to a conversation and thus entertain or engage the 
listeners by virtue of the verbal creativity manifested in the proverb's poetic quality (ibid:70).

Akmajian et al. (2001: 385) highlight the role of language in use, and explain that "proverbs are traditional sayings having a fixed general sentential form, alluding to common truth or general wisdom, with some (rudimentary) literary value, used to guide action, explain a situation, or induce a feeling or attitude"

\subsection{Animals in Proverbs}

Animals can be considered the most distinguished source of proverbs in every nation. They form a major part in the heritage of proverbs in every environment. Since proverbs reflect the morals and customs of people everywhere, it is easy for every researcher to discover the role of animals in them.

Arabs, like other nations have extracted a great deal of their proverbs from the animal words especially those of close contact with their environment. It is familiar to find that Arab proverbs compare between human and animal deeds. Rural proverbs in Iraq exceed all other proverbs in using animal in their texts.

No one can ignore the importance of proverbs among English people. Animal proverbs find their own considerable place on the pages of The Oxford Dictionary of Proverbs (2004), from which the English data of this paper is taken.

\section{Pragmasty listics}

As the name suggests and according to Hickey (1993:578) pragmastylistics is a combination of the components of stylistics with those of pragmatics. Pragmastylistics deals with how a speaker or a writer chooses certain features 
from a list which contains the same semantic equivalents in his/ her language, that achieve different performances. The choice is conditioned and determined by the communicative regulations of the linguistic and physical context of situation. While the pragmatic role in language is using the intended and required utterances governed by their context of situation, the role of stylistics is to anylyse the features and tools used in these utterances to highlight its strong bond as a linguistic approach to study spoken and written language.

\subsection{Stylistics}

Generally speaking, stylistics is known as a linguistic approach to study a written or a spoken language. It is also known that stylistics is the linguistic approach to study literature. The main characteristic of stylistics is 'objectivity' in describing the linguistic features that shape the style of a writer or a speaker in using a language. Hocket (1958:556) cited in Hickey (1993:573) simply defines style as "Roughly speaking, two utterances in the same language which convey approximately the same information but which are different in their linguistic structure can be said to differ in style" The choice between the structures or features available to the writer or the speaker is called stylistics. "By its very form the term "stylistics" suggests a scientific, orderly, objective study of style, as a distinct from an intuitive or impressionistic reaction to a particular text" (ibid:574).

The main task of stylistic analysis is to highlight the artistic principles characterize a writer's choice of language (AL-Janabi, 2015:255).

\subsection{Pragmatics}

Pragmatics is the discipline that approaches the meaning of the language according to its contextual situation. It deals directly with the use of language. 
Verschueren (1999:1) gives a clear definition of pragmatics as "the study of language use". Yule (1996:3) defines pragmatics as "the study of speaker meaning" and he affirms that "Pragmatics is concerned with the study of meaning as communicated by a speaker (or writer) and interpreted by a listener (or reader)" Mey (1993:42) asserts that conditions of society govern the use of language. Thus, he defines pragmatics as "the study of the conditions of human language uses as these are determined by the context of society"

Pragmatics studies and gives solutions to the conversational situations through many areas of discourse. Levinson (1983:27) gives some of these areas "Pragmatics is the study of deixis (at least in part), implicature, presupposition, speech acts, and aspect of discourse structure".

\subsubsection{Speech Acts}

Speech act is a term used to refer to "a theory which analyses the role of UTTERANCE in relation to the behaviour of speaker and hearer in interpersonal communication".

Levinson (1983:236) mentions that Austin isolates three basic senses in which in saying something one is doing something" He mentions the following three kinds of acts that are simultaneously performed:

i) locutionary act: the utterance of a sentence with determinant sense and reference

(ii) illocutionary act: the making of a statement, offer, promise, etc. in uttering a sentence, by virtue of the conventional force associated with it (or with its explicit performative paraphrase)

(iii) perlocutionary act: the bringing about of effects on the audience by means of uttering the sentence, such effects being special to the circumstances of utterance 
Yule (1996:53-4) mentions that the general classification system lists five types of general functions performed by speech acts:

- Assertives are the speech acts that state what the speaker believes to be the case or not.

- Directives are the speech acts that express what the speaker wants

- Commissives are the speech acts that express what the speaker intends

-Expressives are the speech acts that express psychological states and can be statements of pleasure, pain, likes, dislikes, joy, or sorrow.

-Declarations are the speech acts that change the world via their utterance

\subsection{Anaphoric Reference}

Anaphoric Reference "is one way of marking the identity between what is being expressed and what has already been expressed' (Crystal, 2003:24). Anaphoric reference as Levinson (1983:85) explains "concerns the use of (usually) a pronoun to refer to the same referent as some prior term," as in:

Harry's a sweetheart; $h e^{\prime}$ s so considerate

(ibid)

\section{Data Analysis}

Owolabi, (2010) opines that the study of proverbs as an important aspect of language now "has two approaches to it; paremiography and paremiology. Paremiography deals with collection of proverbs of different regions and cultures while paremiology is the study of the collected proverbs." Putting these principles in mind, the proverbs of this study are selected .

\subsection{Domestic Animals in English proverbs}

The selected English proverbs are extracted from The Oxford dictionary of Proverbs (2004). The selection of each proverb depends on two bases:

1. It must use an animal as its main topic. 
2. It must have a counterpart in the Iraqi rural proverbs with the same semantic referent and can be used pragmatically in the same context of situation. All the proverbs of The Oxford dictionary of Proverbs (2004) are studied and investigated for animal proverbs. All such types of proverbs are extracted and ten of them are selected according to the availability of a counterpart or a semi- counterpart for each in the Iraqi Rural Proverbs.

\subsection{Domestic Animals in Iraqi Rural Proverbs}

The proverbs of this type are experienced by the researcher himself. As a member of an Iraqi rural area, the researcher finds no need for informants or resources to document them. The researcher is familiar with these proverbs, their uses in suitable contexts and their adoption as communicative approaches in pragmatic conversations. Ten proverbs that match the English proverbs in their conversational use are chosen from the researcher experience (they are familiar and well known by every rural person).

The following is a table for juxtaposing the English and the Iraqi rural proverbs selected for the purpose of analysis in this study.

Table 1 English and Iraqi rural proverbs

\begin{tabular}{|c|c|c|}
\hline & English Proverbs & Iraqi Rural Proverbs \\
\hline 1 & Love me love my dog & 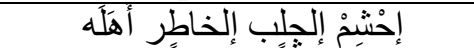 \\
\hline 2 & $\begin{array}{c}\text { What can you expect from a } \\
\text { pig but a grunt }\end{array}$ & إلِلي يلاعب البزون يتحمل خر اميشة \\
\hline 3 & $\begin{array}{l}\text { The fish always stinks from } \\
\text { the head downwards }\end{array}$ & السِمِجة خايسة من ر اسهها \\
\hline 4 & $\begin{array}{c}\text { Every cock will crow upon his } \\
\text { own dunghill }\end{array}$ & إلديجه ما يعو عي الا على مِزْبِلِة أهَلَّة \\
\hline 5 & Dog does not eat dog & جلب ما ياكل جلب \\
\hline
\end{tabular}




\begin{tabular}{|c|c|c|}
\hline 6 & A bleating sheep loses a bite & النعجة ما تثغي خاف تفوتهه لكمة \\
\hline 7 & $\begin{array}{l}\text { A bird in the hand is worth } \\
\text { two in the bush }\end{array}$ & عصفور باليد أخّير من عشرة عالسجرة \\
\hline 8 & Big fish eat little fish & السِمجَج ناس تاكِل ناس \\
\hline 9 & $\begin{array}{l}\text { When the cat's away, the mice } \\
\text { will play }\end{array}$ & لو غاب الخُط إلعَبْ يا فار \\
\hline 10 & $\begin{array}{l}\text { It is too late to shut the sable- } \\
\text { door after the horse has bolted }\end{array}$ & يحل الكُر ويظل يحاويلة \\
\hline
\end{tabular}

\section{Methodology}

The pragma stylistic study of the data is approached within the following steps:

1. Giving a key to the transliterating symbols.

2. Drawing up a comprehensive table with three main columns; the first for the number of each pairs of proverbs, the second for the English proverbs and the third for the Arabic proverbs with their transliteration and translation.

3. Each pairs of proverbs are juxtaposed in the table.

4. The main table is subdivided into two parts, one for the stylistic analysis and one for the pragmatic analysis.

\begin{tabular}{|c|c|c|c|c|c|c|}
\hline \multicolumn{3}{|c|}{ Contents } & & \multicolumn{3}{|c|}{ Vowels and Diphthong } \\
\hline Symbol & & & Symbols & Vowels & & \\
\hline$?$ & 4 & ماء & $\overline{\mathrm{a}}$ & ì & [bāb] & door \\
\hline $\mathrm{b}$ & ب ب & باب [ baba] & $\overline{1}$ & ي & [sa Pīid] & happy \\
\hline $\mathrm{t}$ & ت & ت t tinn] تين & $\overline{\mathrm{u}}$ & 9 & [qulūb] & heart \\
\hline th & $\dot{H}$ & [ thamī n] ثمين & $\mathrm{O}$ & & [fog] & above \\
\hline $\mathrm{j}$ & ج & جديد ] jadīd] & $\overline{\mathrm{O}}$ & & [jōz] & husband \\
\hline h & $\tau$ & حرب ] harb] & & & & \\
\hline kh & $\dot{\tau}$ & خبز [khubz] & & & & \\
\hline $\mathrm{d}$ & ב & دار ] daar] & & & & \\
\hline $\mathrm{dh}$ & $\dot{j}$ & ذيل [dhayl] & aw & و & & death \\
\hline
\end{tabular}




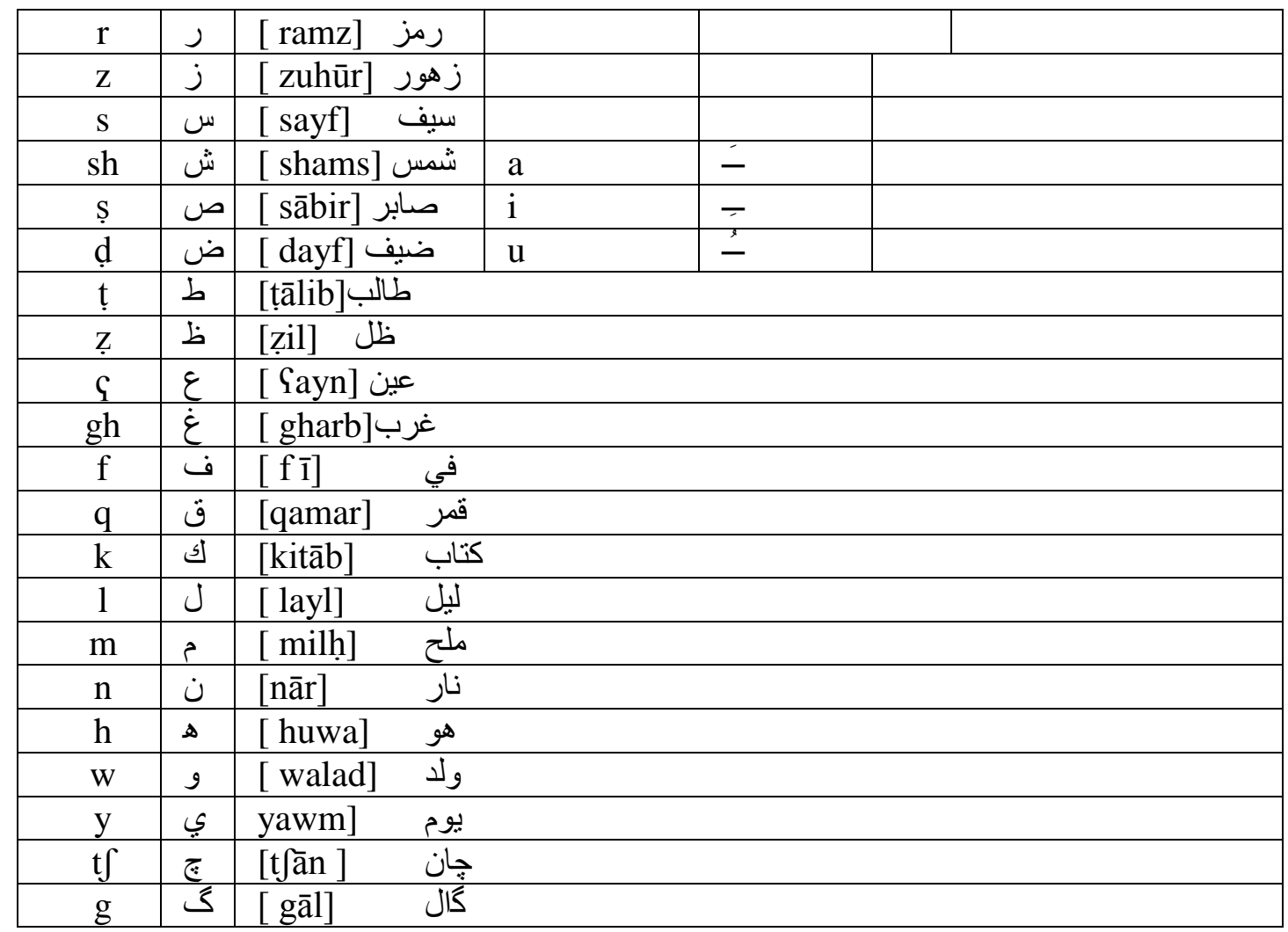

5.The stylistic analysis covers the following devices: simple sentences, compound sentences, the length of sentence, the number and percentage of adjectives and adverbs), tracing the existence of metaphor, alliteration and repetition.

6. The pragmatic analysis aims at finding the semantic and pragmatic matching between the proverbs of each pairs. The illocutionary force of each proverb and the type of speech acts of the verbs, are investigated. Anaphoric reference is also examined as a pragmatic device.

7. Result analysis depends on a comprehensive table summarizing all the previous areas.

8. Drawing up a conclusion.

9. When the two proverbs are similar the same analysis is used for both.

\section{Data Analysis}


This paper adopts and limits itself to the steps of the methodology as a model of analysis

\subsection{Key to Transliteration}

The symbols in the following table are adopted in transliterating the Iraqi rural proverbs to facilitate their pronunciation.

\section{Table 2 Key to the transliteration Symbols}

Al-Janabi (2016: 2016)

\subsection{Analysis of the Proverbs}

The English and Iraqi rural proverbs are juxtaposed in pairs in the following table for purpose of semantic and pragmatic analysis. The English proverbs are marked by the numbers of their pages in The Oxford dictionary of Proverbs (2004.The Iraqi rural proverbs are transliterated and translated.

\section{Table 3 Analysis of the Proverbs}

\begin{tabular}{|c|c|c|}
\hline No. & English Proverb & Iraqi Rural Proverb \\
\hline \multirow[t]{3}{*}{1} & Love me love my dog p.189 & 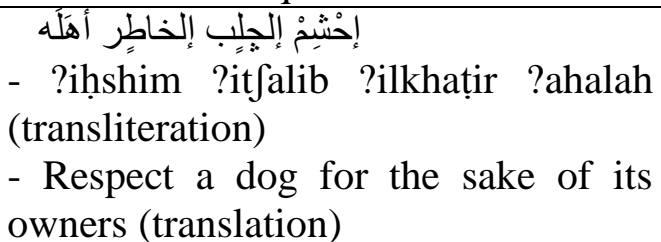 \\
\hline & Stylistic Analysis & \\
\hline & $\begin{array}{l}\text { The English proverb shows some } \\
\text { stylistic devices like: } \\
\text { - The proverb contains } 2 \text { simple } \\
\text { sentences. } \\
\text { - The sentences contain } 5 \text { words. } \\
\text { - There are } 3 \text { content words (love } \\
2 \text {, and dog) with a percentage of } \\
60.5 \% \text { and } 2 \text { grammatical words } \\
\text { (me and my) with a percentage of } \\
40 \% \\
\text {-There are (1noun and } 2 \text { verbs). } \\
\text { - Metaphor } \\
\text { - repetition } \\
\text {-Alliteration }\end{array}$ & 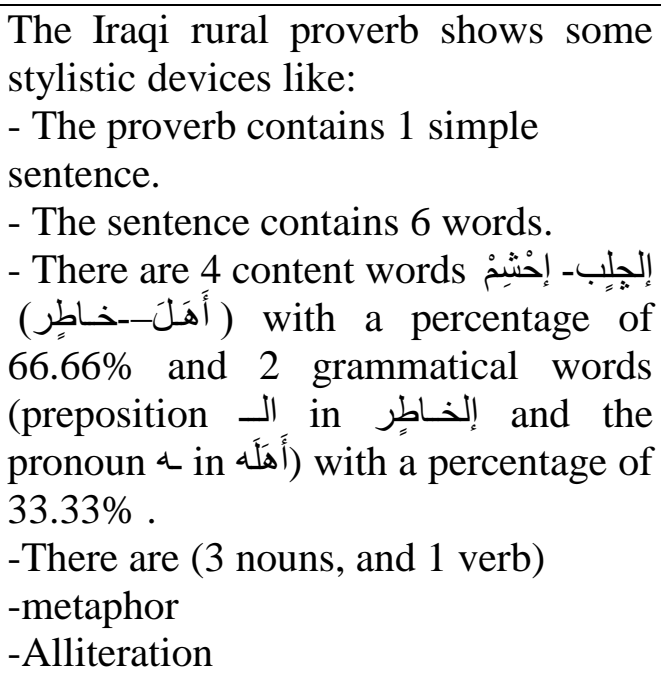 \\
\hline
\end{tabular}


Pragmatic Analysis

Semantically, this English proverb Semantically, this Iraqi rural proverb has the meaning of loving a dog by the same way of loving its owner. Pragmatically, this proverb has indirect meaning to love not only the people but to love all their relatives, belongings, deeds,

behaviours etc. To understand the exact area referred to by this proverb, one needs to be familiar with the context of situation of it.

- This proverb has the illocutionary force of directives (ordering). has the meaning of respecting a dog by the same way of respecting its owner.

Iraqi rural homes often protected by dogs. These dogs are usually trained as guard dogs. They are not chained but free to confront and chase strangers whether humans or animals. It is the tradition in Iraqi rural areas that dogs should be treated as members of their own families, and should be respected accordingly.

Pragmatically, this proverb has indirect meaning to respect not only the people but to love everything belongs to them including their dogs.

- This proverb has the illocutionary force of directives (ordering).

- Anaphoric reference between the pronoun(L) and the word إليلب

-The difference in wording between the two proverbs does not affect their meaning semantically and pragmatically.

- The English proverb is longer than the Iraqi proverb.

\begin{tabular}{|c|c|c|}
\hline & \multirow[b]{2}{*}{$\begin{array}{l}\text { English Proverb } \\
\text { What can you expect from a pig but } \\
\text { a grunt p. } 100\end{array}$} & ral Proverb \\
\hline & & $\begin{array}{l}\text { اللي يلاعب البزون يتحمل خر اميشه ?illi ylaçib ?ilbazūn ?ytahamal } \\
\text { kharāmyshah (transliteration) } \\
\text { Who plays with a cat bears its } \\
\text { scratches (translation) }\end{array}$ \\
\hline & \multicolumn{2}{|c|}{ Stylistic Analysis } \\
\hline & $\begin{array}{l}\text { The English proverb shows some } \\
\text { stylistic devices like: } \\
\text {-this proverb contains a simple } \\
\text { sentence. }\end{array}$ & $\begin{array}{l}\text { The Iraqi rural proverb shows some } \\
\text { stylistic devices like: } \\
\text {-this proverb contains a complex } \\
\text { sentence. }\end{array}$ \\
\hline
\end{tabular}




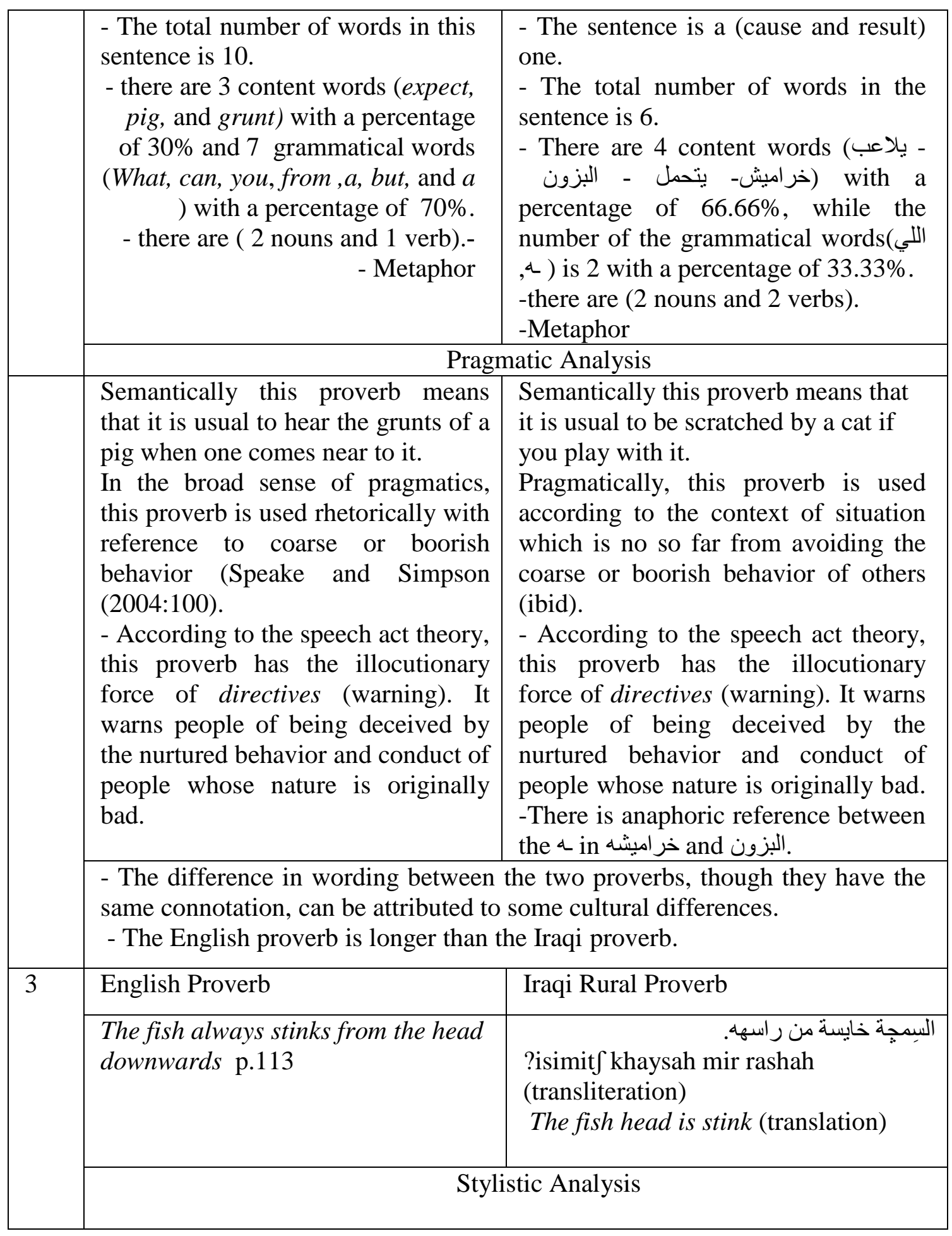


The English proverb shows some stylistic devices like:

-The proverb contains one simple sentence.

- The sentence contains 8 words.

- There are 5 content words (fish, always, stinks, head, downwards) with a percentage of $62.5 \%$ and 3 grammatical words (the 2, from) with a percentage of $37.5 \%$.

-There are (2 nouns, 1 verb, and 2 adverbs).

-Metaphor
The Iraqi rural proverb shows some stylistic devices like:

-The proverb contains one simple sentence.

- The sentence contains 5 words.

- There are 3 content words (السِيجة), with a percentage of 60\% and 2 grammatical words (ن), a)

With a percentage of $40 \%$.

-There are (2nouns, and 1 adjective).

-Metaphor

\section{Pragmatic Analysis}

-Semantically this proverb means that the freshness of a dead fish can be judged from the condition of its head.

- The use of this proverb is governed by its context of situation. Indirectly, this proverb has the meaning that when the responsible part (as the leader of a country, etc) is rotten, the rest will soon follow (Speake and Simpson (2004:113).

- This proverb has the illocutionary force of Representatives (asserting). It Asserts that if the head of any group is corrupted, nothing will be expected from the other members of the group except corruption.
-Semantically this proverb means that the freshness of a dead fish can be judged from the condition of its head.

- The use of this proverb is governed by its context of situation.

Indirectly, this proverb has the meaning that when the responsible part (as the leader of a country, etc) is rotten, the rest will soon follow (Speake and Simpson (2004:113).

- This proverb has the illocutionary force of Representatives (asserting). It assert that if the head of any group is corrupted, nothing will be expected from the other members of the group except corruption.

-There is an anaphoric reference between the pronoun $\alpha$ in راسهة and the noun السبِيجة

-The two proverbs have the same meaning semantically. Both have the same pragmatic use.

-The English proverb is longer than the Iraqi rural proverb. 
Every cock will crow upon his own dunghill p.5
إلديج يعو عي على مِزْبِلِة أهَلَة

?idyt $\int$ ?içọ̄y çala mizbalt ?ahalah (transliteration)

A cock crows upon the dunghill of its owners.(translation)

Stylistic Analysis

The English proverb shows some stylistic devices like:

-The proverb contains one simple sentence.

-The sentence contains 8 words.

- There are 5 content words (every. cock. crow, own. and dunghill) with a percentage of $62.5 \%$ and 3 grammatical words (will, upon. and his) with a percentage of $37.5 \%$.

-There are (2 noun, 1 verb, and 2 adjectives).

-Metaphor

- Alliteration
The Iraqi ryral proverb shows some stylistic devices like:

-The proverb contains one simple sentence.

-The sentence contains 6 words.

- There are 4 content words

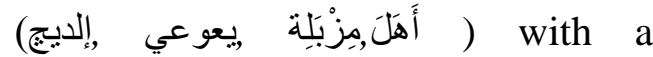
percentage of $66.66 \%$ and 2 grammatical words (على, L with a percentage of $33.33 \%$.

-There are (3nouns and 1 verb).

-Metaphor

- Alliteration

\section{Pragmatic Analysis}

-Semantically this proverb means that every crow fears nothing while crowing upon the dunghill of its owners.

-Pragmatically speaking, this proverb means indirectly that everyone is confident or at ease when on home ground (Speake and Simpson (2004:113).

This proverb, from the prospect of speech theory, has the illocutionary force of Representatives (concluding). The majority of contexts of this proverb are the situations in which some people show off their unreal courage in a safe place that no one can challenge
-Semantically this proverb means that every crow fears nothing while crowing upon the dunghill of its owners.

-Pragmatically speaking, this proverb means indirectly that everyone is confident or at ease when on home ground (ibid). This proverb, from the prospect of speech theory, has the illocutionary force of Representatives (concluding). The majority of contexts of this proverb are the situations in which some people show off their unreal courage in a safe place that no one can challenge them. -There is an anaphoric reference between the pronoun $ه$ in 


\begin{tabular}{|c|c|c|}
\hline & them. & noun \\
\hline & \multicolumn{2}{|c|}{$\begin{array}{l}\text {-The two proverbs have nearly the same wording. } \\
\text { - The English proverb is longer than the Iraqi rural proverb. } \\
\text {-The two proverbs have the same meaning semantically and pragmatically. }\end{array}$} \\
\hline \multirow[t]{6}{*}{5} & English Proverb & Iraqi Rural Proverb \\
\hline & Dog does not eat dog p.78 & $\begin{array}{l}\text { جلب ما ياكِل جلب } \\
\text { talib ma yakil talib (transliteration) } \\
\text { Dog does not eat dog (translation) }\end{array}$ \\
\hline & \multicolumn{2}{|c|}{ Stylistic Analysis } \\
\hline & $\begin{array}{l}\text { The English proverb shows some } \\
\text { stylistic devices like: } \\
\text {-This proverb contains only one } \\
\text { simple negative sentence. } \\
\text {-The sentence contains } 5 \text { words. } \\
\text { - There are } 3 \text { content words ( } \text { dog } 2 \text {, } \\
\text { and eat) with a percentage of } 60 \% \\
\text { and } 2 \text { grammatical words (does, and } \\
\text { not) with a percentage of } 40 \% \text {. } \\
\text {-There are ( } 2 \text { nouns, and } 1 \text { verb). } \\
\text { - Metaphor } \\
\text { - Alliteration } \\
\text {-Repetition }\end{array}$ & 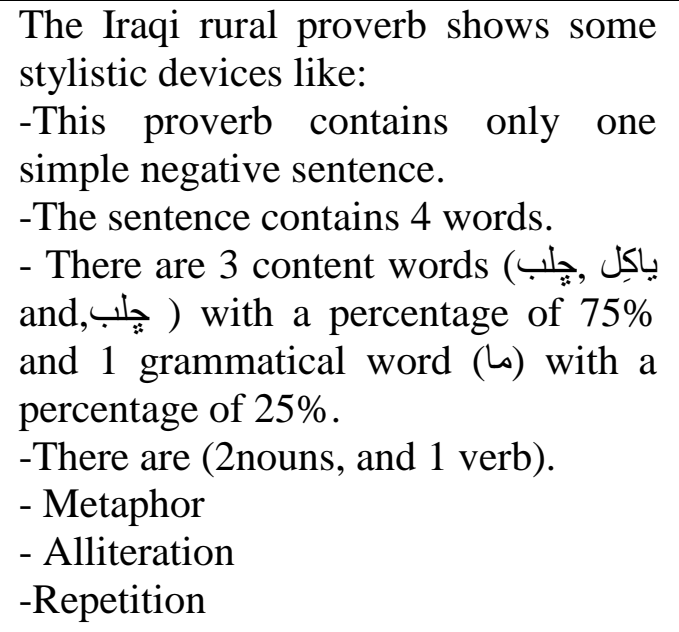 \\
\hline & \multicolumn{2}{|c|}{ Pragmatic analysis } \\
\hline & $\begin{array}{l}\text {-Semantically, this proverb means } \\
\text { that dogs do not eat each others. } \\
\text { This proverb is suitable in a context } \\
\text { of situation when a bad person is } \\
\text { asked to stand against other bad } \\
\text { persons of the same career. A } \\
\text { corrupted or disreputable person will } \\
\text { never harm disreputable persons. } \\
\text { - This proverb has the illocutionary } \\
\text { force of directives (advising). It } \\
\text { advises people not to ask the help of } \\
\text { a bad person against another bad }\end{array}$ & $\begin{array}{l}\text { Semantically, this proverb means that } \\
\text { dogs do not eat each others. } \\
\text { This proverb is suitable in a context of } \\
\text { situation when a bad person is asked to } \\
\text { stand against other bad persons of the } \\
\text { same career. A corrupted or } \\
\text { disreputable person will never harm } \\
\text { disreputable persons. } \\
\text { - This proverb has the illocutionary } \\
\text { force of directives (advising).It advises } \\
\text { people not to ask the help of a bad } \\
\text { person against another bad person. }\end{array}$ \\
\hline
\end{tabular}




\begin{tabular}{|c|c|c|}
\hline & person. & \\
\hline & \multicolumn{2}{|c|}{$\begin{array}{l}\text {-Both, English and the Iraqi rural proverb hold a complete wording, semantic, } \\
\text { and pragmatic sameness in using this proverb. } \\
\text { - The English proverb is longer than the Iraqi rural proverb. } \\
\text { - The two proverbs have the same meaning pragmatically. }\end{array}$} \\
\hline \multirow[t]{5}{*}{6.} & English Proverb & Iraqi Rural Proverb \\
\hline & A bleating sheep loses a bite p.28 & 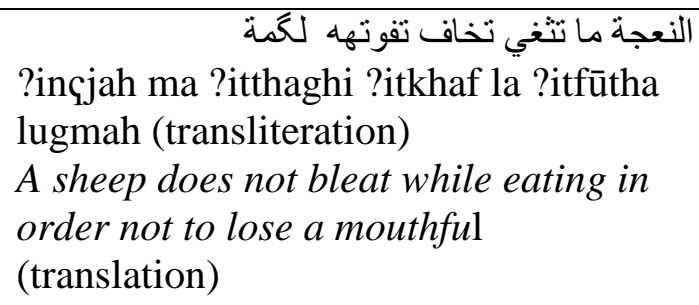 \\
\hline & \multicolumn{2}{|c|}{ Stylistic Analysis } \\
\hline & 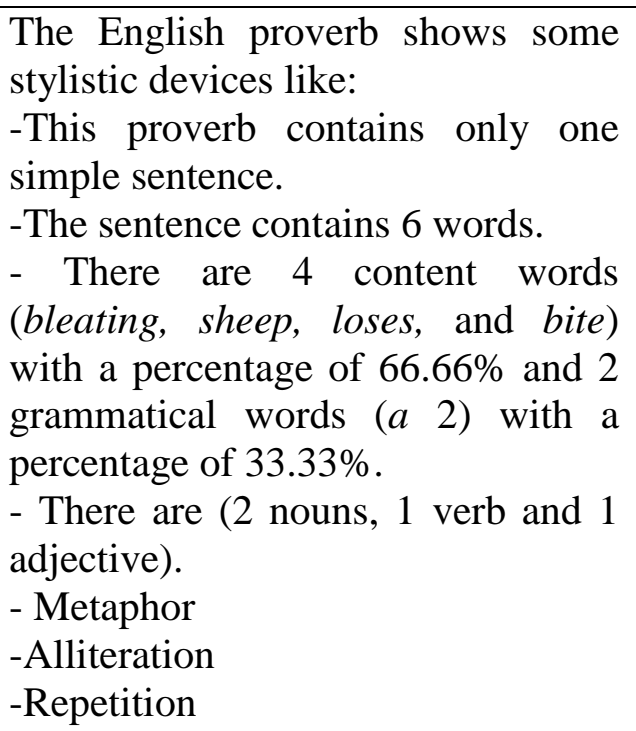 & 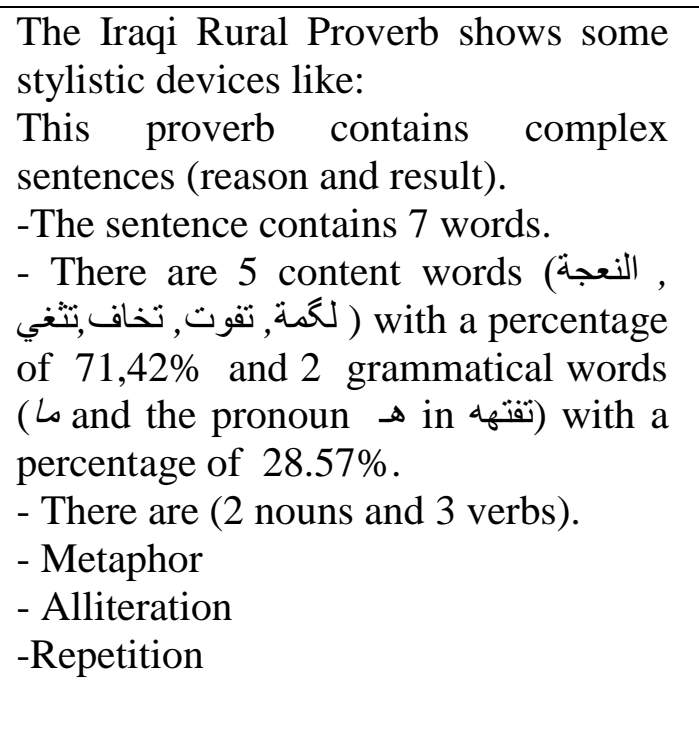 \\
\hline & \multicolumn{2}{|c|}{ Pragmatic Analysis } \\
\hline
\end{tabular}


Semantically, this proverb means that a sheep will lose some mouthfuls the time it bleats.

Pragmatically, this proverb refers to the act of missing some good opportunities while involving in some fruitless actions -like chatters- see (Speake and Simpson (2004:28).

- This proverb has the illocutionary force of directives (advising).It advises people notto lose good opportunities by bothering themselves in something not beneficial.
Semantically, this proverbs means that a sheep try not to bleat while eating in order not to lose some mouthfuls. Pragmatically, this proverb refers to the act of missing some good opportunities while involving in some fruitless actions -like chatters- (ibid).

- This proverb has the illocutionary force of directives (advising).It advises people not lose good opportunities by bothering themselves in something not beneficial.

-Anaphoric reference between the pronoun هand the noun النعجة.

-The two proverbs have nearly the same wording.

- The Iraqi Rural Proverb is longer than the English proverb.

-The two proverbs have the same meaning semantically and pragmatically.

\begin{tabular}{|c|c|c|}
\hline \multirow{2}{*}{7} & \multirow{2}{*}{\begin{tabular}{|l|}
\multicolumn{1}{|c|}{ English Proverb } \\
$\begin{array}{l}\text { A bird in the hand is worth two in } \\
\text { the bush } \mathrm{p} .26\end{array}$
\end{tabular}} & Iraqi Rural Proverb \\
\hline & & 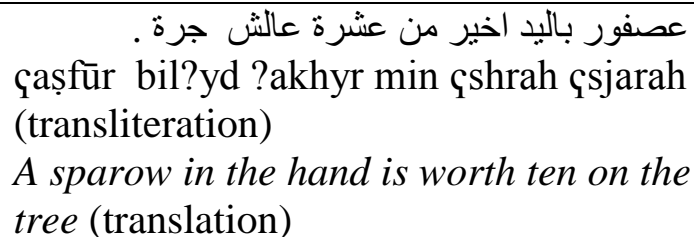 \\
\hline
\end{tabular}


The English proverb shows some stylistic devices like:

-This proverb contains only one simple sentence.

-The sentence contains 11 words.

- There are 6 content words (bird, hand, is (main verb) worth, two, and bush) with a percentage of $54.54 \%$ and 5 grammatical words $(a$, in, the, in, the $)$ with a percentage of $45.45 \%$.

- There are (4 nouns, 1 verb and 1 adjective).

- Metaphor

-Alliteration
The Iraqi rural proverb shows some stylistic devices like:

-This proverb contains only one simple sentence.

-The sentence contains 8 words.

- There are 5 content words (سيد , عصفور with a percentage of $62.5 \%$ and 3 grammatical words (-, (على with a percentage of $37.5 \%$, and

- There are (4 nouns, 1 verb and 1 adjective).

- Metaphor

-Alliteration

\section{Pragmatic Analysis}

Semantically, this proverbs means that a bird in hand is better than two in the bush.

Pragmatically, this proverb says that it is better to accept or be content with what one has than to try to get more and risk losing everything (Speake and Simpson, 2004:26).

- This proverb has the illocutionary force of directives (advising). It advises people not to risk things they have for unguaranteed things.
Semantically, this proverb means that a sparrow in hand is better than ten on the tree.

Pragmatically, this proverb says that it is better to accept or be content with what one has than to try to get more and risk losing everything (ibid)

- This proverb has the illocutionary force of directives (advising). It advises people not to risk things they have for unguaranteed things.

-The English proverb uses the word bird instead of sparrow used in the Iraqi rural proverb, as a prototype of birds, to generalize the situation.

- The English proverb is longer than the Iraqi rural proverb.

-The two proverbs have the same meaning pragmatically and can be used in similar context of situation.

\begin{tabular}{|c|c|c|}
\hline 8 & English Proverb & Iraqi Rural Proverb \\
\hline & Big fish eat little fish p. 25 & السِيمجَ ناس ناكِل ناس (transliteration) \\
\hline
\end{tabular}


Fish eat each other (translation)

Stylistic Analysis

The English proverb shows some The Iraqi rural proverb shows some stylistic devices like:

-This proverb contains only one simple sentence.

-The sentence contains 6 words.

- There are 6 content words (Big, fish, eat, little, and fish) with a percentage of $100 \%$ and there are no grammatical words.

- There are (4 nouns, 1 verb and 1 adjective).

- Metaphore

-Repetition stylistic devices like:

-This proverb contains only one simple sentence.

-The sentence contains 4 words.

- There are 4 content words ( النِيمجَ)

, ناس ,ناكِل ,ناس with a percentage of $100 \%$ and there are no grammatical words.

- There are (3 nouns, and 1 verb).

- Metaphor

-Alliteration

-Alliteration

-Repetition

\section{Pragmatic Analysis}

Semantically, this proverb means that big fish eat little fish.

Pragmatically, this proverb indicates the state today... seems like nothing so much [as] a huge aquarium...Big fish eat little fish, and the great fish eat the big (Speake and Simpson,2004:26).

- This proverb has the illocutionary force of directives (warning). It warns us of the human whales and their dominant abilities to destroy the lower people.

-The English proverb uses (big fish) while the Iraqi rural proverb uses (fish) to imply the nature of the big fish to eat the little one. - The English proverb is longer than the Iraqi rural proverb.

-The two proverbs have the same meaning semantically and pragmatically and can be used in the same context of situation. 


\begin{tabular}{|c|c|c|}
\hline & $\begin{array}{l}\text { When the cat's away, the mice will } \\
\text { play p. } 44\end{array}$ & $\begin{array}{l}\text { لو غاب الكُط إلعَبْ يا فار. } \\
\text { lo ghab ?ilgut ?ilçab yā făr } \\
\text { (transliteration) } \\
\text { When the cat's away, the mice will } \\
\text { play (translation) }\end{array}$ \\
\hline & \multicolumn{2}{|c|}{ Stylistic Analysis } \\
\hline & $\begin{array}{l}\text { The English proverb shows some } \\
\text { stylistic devices like: } \\
\text {-This proverb contains a complex } \\
\text { sentence (reason and result). } \\
\text { - The sentence contains } 9 \text { words. } \\
\text { - There are } 5 \text { content words (cat, is, } \\
\text { away, mice, and play) with a } \\
\text { percentage of } 55.55 \% \text { and } 4 \\
\text { grammatical words (when, the } 2 \text {, } \\
\text { and will) with a percentage of } \\
44.44 \% \text {. } \\
\text { - There are ( } 2 \text { nouns, } 2 \text { verbs and } 1 \\
\text { adverb). } \\
\text { - Metaphor } \\
\text {-Alliteration }\end{array}$ & 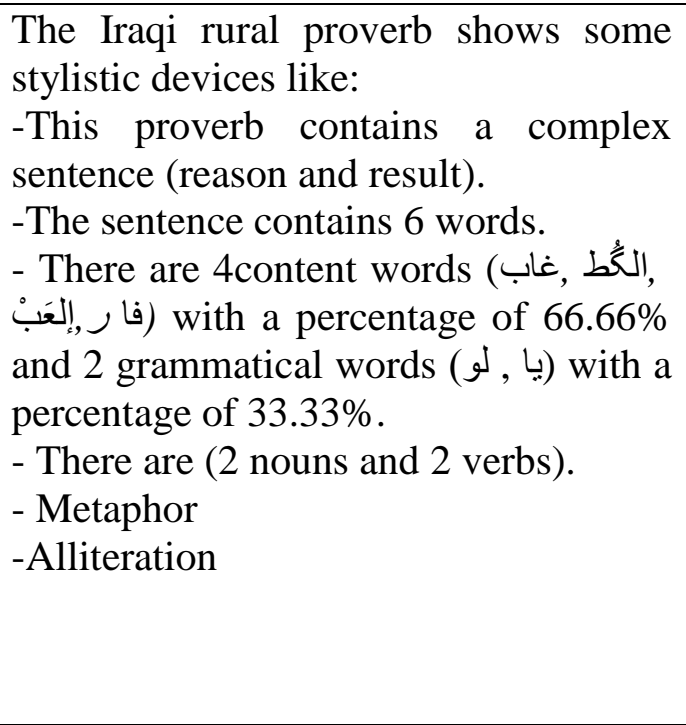 \\
\hline & \multicolumn{2}{|l|}{ Pragmatic Analysis } \\
\hline & $\begin{array}{l}\text { Semantically, this proverbs means } \\
\text { that a mouse plays only when there } \\
\text { is no cat. } \\
\text { Pragmatically, this proverb indicates } \\
\text { discipline and opportunity taken } \\
\text { (Speake and Simpson, 2004:44). } \\
\text { - This proverb has the illocutionary } \\
\text { force of directives (both warning } \\
\text { and advising). It warns of the } \\
\text { wicked people to avail the absence } \\
\text { of power to break rules and orders. }\end{array}$ & $\begin{array}{l}\text { Semantically, this proverbs means that } \\
\text { a mouse plays only when there is no } \\
\text { cat. } \\
\text { Pragmatically, this proverb indicates } \\
\text { discipline and opportunity taken (ibid). } \\
\text { - This proverb has the illocutionary } \\
\text { force of directives (both warning and } \\
\text { advising). It warns of the wicked people } \\
\text { to avail the absence of power to break } \\
\text { rules and orders. }\end{array}$ \\
\hline & \multicolumn{2}{|c|}{$\begin{array}{l}\text { - The English proverb is longer than the Iraqi rural proverb. } \\
\text {-The two proverbs have the same meaning semantically and pragmatically and } \\
\text { can be used in the same context of situation }\end{array}$} \\
\hline 10 & English Proverb & Iraqi Rural Proverb \\
\hline
\end{tabular}


It is too late to shut the stable-door after the horse has bolted p.289
يحل الكُر ويظل بحاويلة

?iy hil ilkur wiydhal ?iḥawylah (transliteration)

Untie the donley and beseeches it to come (translation)

Stylistic Analysis

The English proverb shows some stylistic devices like:

-This proverb contains a complex sentence (reason and result).

-The sentence contains 14 words.

- There are 8 content words (is, late, shut, stable, door, after, horse, and bolted) with a percentage of $57.14 \%$ and 6 grammatical words (It, too, to, the 2, has) with a percentage of $42.85 \%$.

- There are (3 nouns, 3 verbs, 1 adjectives and 1 adverb).

- Metaphor -Alliteration
The Iraqi rural proverb shows some stylistic devices like:

-This proverb contains a complex sentence (reason and result)

A -This proverb contains a complex sentence (reason and result).

-The sentence contains 7 words.

- There are 4 content words (الكُر ,يحل), ( ) with a percentage of $57.14 \%$ and 3 grammatical words $(,$, $ه)$ with a percentage of $42.85 \%$.

- There are (1 noun, and 3 verbs).

- Metaphor

-Alliteration 
Semantically, this proverb means that it is useless to shut the stable door after the horse has bolted.

Pragmatically, this proverb indicates foresight and hindsight; futality; and lateness (Speake and Simpson, 2004:44).

-Cambridge Advanced Learner's Dictionary \& Thesaurus defines this proverb "to be so late in taking action to prevent something bad happening that the bad event has already happened"

- This proverb has the illocutionary force of directives (advising and warning). It advises people not to pay great attention to what they have and don not waste them irrationally
Semantically, this proverb means that some people untie their donkeys and bother themselves to catch them.

Pragmatically, this proverb indicates foresight and hindsight; futality; and lateness (Speake and Simpson, 2004:44).

-Cambridge Advanced Learner's Dictionary \& Thesaurus defines this proverb "to be so late in taking action to prevent something badhappening that the bad event has already happened'

- This proverb has the illocutionary force of directives (advising and warning). It advises people not to pay great attention to what they have and don not waste them irrationally.

-Anaphoric reference between the pronoun $\propto$ and the noun الكر.

-The English proverb uses (horse) while the Iraqi rural proverb uses (donkey), still the meaning is the same. The English proverb is longer than the Iraqi rural proverb.

-The two proverbs have the same meaning semantically and pragmatically and can be used in the same context of situation.

\section{Discussing the Results}

The above table illustrates some similarities and differences between the two types of proverbs.

\begin{tabular}{|l|l|l|l|l|}
\hline \multicolumn{5}{|c|}{ Stylistic analysis } \\
\hline \multirow{2}{*}{ Fields of Analysis } & English & \multicolumn{2}{l|}{ Iraqi rural proverbs } \\
\cline { 2 - 6 } & No. & $\%$ & No. & $\%$ \\
\hline Simple sentence & 9 & 81.81 & 6 & 60 \\
\hline Complex sentence & 2 & 18.18 & 4 & 40 \\
\hline Total words & 82 & 100 & 59 & 100 \\
\hline Content words & 48 & 58.53 & 40 & 67.79 \\
\hline Grammatical words & 34 & 41.46 & 19 & 32.20 \\
\hline Nouns & 24 & 50 & 24 & 60 \\
\hline
\end{tabular}




\begin{tabular}{|l|l|l|l|l|}
\hline Verbs & 14 & 29.10 & 15 & 37.5 \\
\hline Adjectives & 6 & 12.5 & 1 & 2.5 \\
\hline Adverbs & 4 & 8.33 & 0 & 0 \\
\hline Metaphor & 10 & 100 & 10 & 100 \\
\hline Alliteration & 8 & 80 & 8 & 80 \\
\hline Repetition & 4 & 49 & 3 & 30 \\
\hline Length of sentences (average) & 8.2 words & 5.9 words \\
\hline
\end{tabular}

\subsection{Stylistic Analysis (Results)}

In addition to the analytical explanation within the borders of the previous table, the following table summarizes the results statistically.

\section{Table 4 Stylistic Analysis (Results)}

The table above illustrates that there are some differences in the number and percentages of the stylistic devices used in the two types of the proverbs. The descriptive nature of stylistics entails no need for justification for this difference. A look at the above table is enough to reveal the results of analysis.

\subsection{Pragmatic Analysis (Result)}

The table of analysis demonstrates the following results:

- The English and the Iraqi rural proverbs indicate the same semantic and pragmatic similarities.

- the English and the Iraqi rural proverbs show the use of the same illocutionary forces and show the same number of speech acts ( 4 warning, 3 advising, ordering, I asserting, and 1 concluding) .

- While Iraqi rural proverbs demonstrate 6 anaphoric references, the English proverbs demonstrate none.

\section{Conclusion}

Through a scrutinized study of the analysis of the proverbs and discussing their results, this paper concludes the following: 
1. Despite the great difference between the environments of the English and the Iraqi rural proverbs, they demonstrate the same use of domestic animals in their texts.

2. The English and the Iraqi rural proverbs show exact semantic and pragmatic referents.

3. The English and the Iraqi rural proverbs are used in the same context of situation.

4. In the stylistic analysis the two types of proverbs show similarity in using the devices metaphor, alliteration and repetition, but they demonstrate some linguistic differences in some other devices:

- English proverbs use more simple sentences than Iraqi rural proverbs.

- The Iraqi rural proverbs use more complex sentences than the English proverbs.

-The average of sentences is longer in English proverbs than that in Iraqi rural proverbs.

- The frequency and percentage of content words are higher in the Iraqi rural proverbs than in the English proverbs, while the percentage of the grammatical words is higher in the English proverbs than in the Iraqi rural proverbs.

-The frequency and percentages of nouns and verbs are higher in the Iraqi rural proverbs than in the English proverbs.

- Pragmatically, the two types of proverbs show similarity in using the same illocutionary force and the same type of speech act. The distinctive difference between them is in the use of anaphoric reference; while the Iraqi rural proverbs demonstrate six of them, as in proverbs $(1,2,3,4,6$, and 10) they have no existence in the English proverbs. 


\section{$\underline{\text { References }}$}

1. Akmajian, A., Demers, R. A., Farmer, A. K., and Harnish, R.M. (2001Linguistics: An Introduction to Language and Communication. London: MIT Press.

2. Al- Hanfi, Sh. J. (1962) Al-Amthalul Bagdadiyah. Baghdad Assad's Press.

3. AL-Janabi, M. Kh. H. (2015) "A Stylistic Analysis of Two Selected, English and ARABIC, War Poems". Journal of College of Languages.31/2015 pp.253-279.

4. AL-Janabi, M. Kh. H. (2016) "Lexical and Pronunciation Differences in Selected Palestinian and Baghdadi Proverbs: A dialectical Study" AL-Ma'moon College Journal . Issue 28/2016 pp.2018-244.

5. Attia, Mohammed (2004) Dictionary of Common English Proverbs .Available from http://www.attiaspace.com/Publications/Comm on Proverbs.pdf

6. Barajas, El1'as Domi'nguez (2010) The Function of Proverbs Discourse: The Case of a Mexican Transnational Social Network. New York: De Gruyter Mouton Crystal, D. (2003) A Dictionary of Linguistics and Phonetics $5^{\text {th }}$ Ed. Oxford: Blackwell.

7. Hickey, L. (1993) 'Stylistics, Pragmatics and Pragmastylistics'. In Revue Beige de philology et d' historive. Volume 71 numero 3 pp. 573-586

8. Kerschen, Lois (1998) American Proverbs about Women: a reference guide. London: Greenwood Press.

9. Levinson, C. L. (1983) Pragmatics. Cambridge: Cambridge University Preess.

10. Manser, M,H. ( 2007) The Facts On File Dictionary of Proverbs $2^{\text {nd }}$ Ed.New York: Facts On File, Inc.

11. Mey, J. L. (1993) Pragmatics. Cambridge:Black well.

12. Owolabi, H. F. (2010) "Pragma-Stylistic Investigation of Proverbs in Some Yoruba-Mediated Nollywood Films". Unpublished thesis. University of Ibadan Nigeria.

13. Expression and Meaning: Studies in the Theory of Speech Acts Speak, J. and Simpson, J. eds. (2004) The Oxford Dictionary of 
Proverbs. Oxford: Oxford University Press. Stone, J.R. (2006) The Routledge Book of World Proverbs. London: Routledge.

14. Verschueren. J (1999) Understanding Pragmatics.London: Arnold 15. Wehmeier, S., McIntosh,c., and Turnbull, J. (2005) eds. Oxford Advanced Learner's Dictionary . $7^{\text {th }}$ Ed. Oxford: Oxford University Press.

16. Yule, G. (I996) Pragmatics. Oxford: Oxford University Press.

\section{About the Author}

Dr. Mahdi Kh. Hussein Al- Janabi Asst. Prof. in English Language and Linguistics. Has a long experience in teaching English language. Has an experience in translation. Wrote many researches in Linguistics. Attended many symposiums and conferences inside and outside Iraq.

Email: mah_jan49@yahoo.com

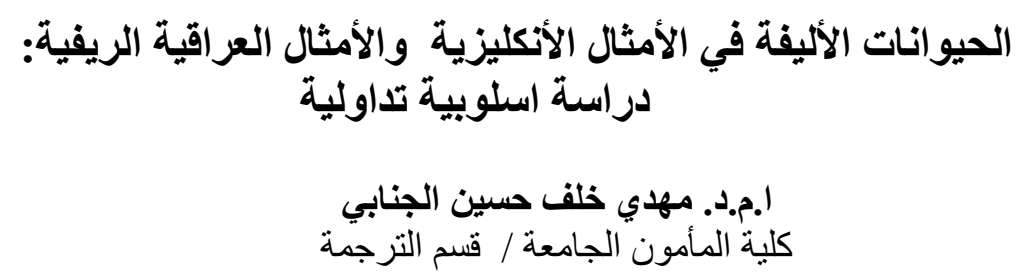

خلاصة البحث

تتأتى اهمية الأمثال ليس فقط من كونها تمثل السجل الحضاري للناس في أية امة من الأمم،

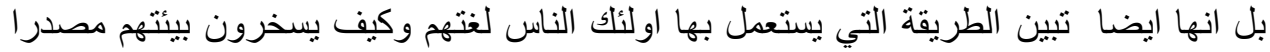
جيدا للألهام لأغناء تللك اللغة. تهدف هذه الدراسة الى تحليل بعض الأمثال الأنكليزية والعراقيبة الريفية والتي استعملت

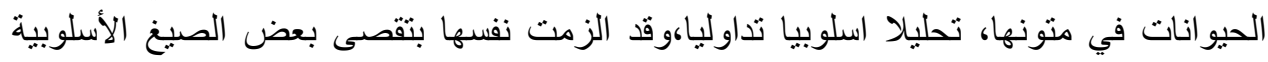

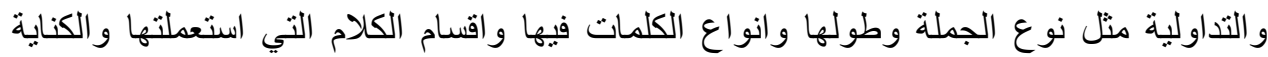

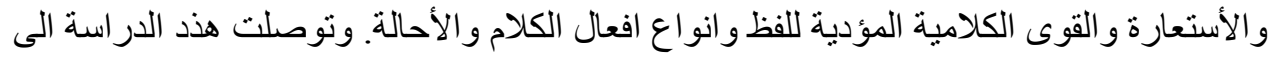

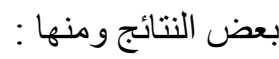

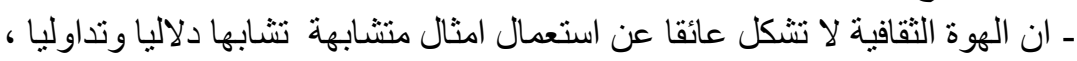

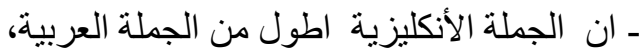
ــ ان الأمثال بنو عيها استعملت نفس القوى اللفطية المؤدية للقيام بذات الأفعال. مفاتيح الكلمات: المثل، الاسلوبية، التداولية، اسلوبية تداولية، نظرية افعال الكلام 